\title{
Up-Regulation of CD163 Expression in Subpopulations of Blood Monocytes After Kidney Allograft Transplantation
}

\author{
Lenka ČURNOVÁ ${ }^{1}$, Kristýna MEZEROVÁ ${ }^{1}$, Veronika ŠVACHOVÁ ${ }^{\mathbf{1}}$, Martina FIALOVÁ ${ }^{\mathbf{1}}$, \\ Marek NOVOTNÝ ${ }^{2}$, Eva ČEČRDLOVÁ ${ }^{1}$, Ondřej VIKLICKÝ ${ }^{2}$, Ilja STŘ́İŽ ${ }^{1}$ \\ ${ }^{1}$ Department of Clinical and Transplant Immunology, Institute for Clinical and Experimental \\ Medicine, Prague, Czech Republic, ${ }^{2}$ Department of Nephrology, Transplant Center, Institute for \\ Clinical and Experimental Medicine, Prague, Czech Republic
}

Received June 17, 2020

Accepted July 28, 2020

Epub Ahead of Print September 9, 2020

\section{Summary}

M2 macrophages expressing CD163 are known to suppress immune responses but have been also found in biopsies of patients with chronic kidney allograft injury associated with interstitial fibrosis. The aim of our study was to evaluate the expression of CD163 in blood monocytes, precursors of tissue macrophages, in kidney allograft recipients with uncomplicated outcome $(n=94)$ compared with those developing acute rejection $(n=44)$. Blood samples were collected before the transplantation and at 1 week, 1 month and 1 year. The expression of CD163 increased during the first week after the transplantation not only in classical $\left(\mathrm{CD} 14^{+} \mathrm{CD} 16^{-}\right)$but also in intermediate $\left(\mathrm{CD} 14^{+} \mathrm{CD} 16^{+}\right)$ and nonclassical $\left(\mathrm{CD} 14^{\text {low }} \mathrm{CD} 16^{+}\right)$monocytes in all patients regardless of their rejection status. In patients developing acute rejection, higher pre-transplant expression of CD163 on blood monocytes was found. In vitro experiments confirmed strong induction of membrane CD163 on monocytes together with CD206 (an alternative marker of M2 macrophages) in response to IL-10. We assume from our data that dramatic upregulation of CD163 by peripheral blood monocytes may have a pathophysiological role in early phases after kidney allograft transplantation and high pre-transplant expression of CD163 on blood monocytes might be involved in events leading to acute rejection.

\section{Key words}

Blood monocytes - Subpopulations - Kidney transplantation • Acute rejection $\bullet \mathrm{CD} 14^{+} \mathrm{CD} 16^{+} \bullet \mathrm{CD} 163$

\section{Corresponding author}

I. Striz, Institute for Clinical and Experimental Medicine, Vídeňská 1958/9, 14021 Prague 4, Czech Republic. E-mail: ilja.striz@ikem.cz

\section{Introduction}

Mononuclear phagocytes at different stages of differentiation from blood monocytes to tissue macrophages and dendritic cells play a key role in the initiation, effector mechanisms and regulation of immune responses (Moghaddam et al. 2018). In kidney transplantation, monocyte infiltration into the graft has been found to correlate with renal dysfunction (Girlanda et al. 2008). Monocytes producing IL-6 are in relationship with a decrease in glomerular filtration rate in patients with borderline changes suspicious for acute T cell-mediated rejection (Desy et al. 2018) but there is also an association between the number of peripheral monocytes and risk of chronic kidney disease in transplant recipients (Bowe et al. 2017). Specific subpopulations can be distinguished among monocytes by the expression level of membrane antigens CD14 (a receptor for bacterial LPS) and CD16 (FcyRIII) (Ziegler-Heitbrock et al. 2010). The "classical" monocytes $\left(\mathrm{CD} 14^{+} \mathrm{CD} 16^{-}\right)$are characterized by a strong CD14 expression in the absence of CD16 on their surface and two subpopulations monocytes have relatively low CD14 expression and detectable CD16 molecule on a membrane being classified as "intermediate" $\left(\mathrm{CD} 14^{+} \mathrm{CD} 16^{+}\right)$and "non-classical" $\left(\mathrm{CD} 14^{\text {low }} \mathrm{CD} 16^{+}\right)$ 
(Wong et al. 2011) (Stansfield and Ingram 2015). These two functionally and phenotypically related subsets (Ong et al. 2019) showed higher pre-transplant numbers in patients developing acute rejection as compared with those with uncomplicated outcome (van den Bosch et al. 2017b).

In tissue macrophages originated from blood monocytes, CD163 expression is a characteristic marker of subpopulation suppressing immune responses known as M2 (alternatively activated) macrophages with a capability to release high amounts of IL-10 (Mayer et al.). CD163 positive macrophages are frequently found in malignant tumors with progressive growth (Shiraishi et al. 2018) and provide local immunosuppressive effects. This well conserved molecule serves as a scavenger molecule for hemoglobin-haptoglobin complexes (Fabriek et al. 2005) and binds cytokine TWEAK (Moreno et al. 2009) or microorganisms (Fabriek et al. 2009). The expression of CD163 in cultured human blood monocytes is upregulated by glucocorticoids, IL-10 and IL-6 (Maniecki et al. 2006) while pro-inflammatory factors including TNF alpha, IFN gamma and LPS downregulate the membrane form. In response to macrophage activation by $\mathrm{Fc}$ gamma cross-linking, LPS stimulation or by oxidative stress, CD163 is proteolytically cleaved by a metalloproteinase ADAM17 (Etzerodt et al. 2014) and undergoes shedding from the membrane of mononuclear phagocytes. This soluble form, sCD163, is detectable in serum and may be used as a biomarker in chronic inflammatory and metabolic diseases (Dige et al. 2014, Smiljanovic et al. 2018, Tanimura et al. 2015, Cinkajzlova et al. 2017).

Most of the studies in organ transplant patients are focused on detection of CD163 positive macrophages in allograft biopsies which represent an invasive option to obtain valuable data on molecular processes in kidney parenchyma (Trailin et al. 2020). In early kidney transplant biopsies, parenchymal infiltration with $\mathrm{CD}_{163^{+}}$macrophages correlated with interstitial inflammation, tubulitis, and peritubular capillaritis scores (Shin et al. 2015).

The presence of $\mathrm{CD} 63^{+}$macrophages in kidney biopsies of antibody-mediated rejection was found to be associated with chronic glomerular injury and poor graft function, but did not significantly affect graft survival (Kim et al. 2018). In T cell mediated rejection of kidney allograft, $\mathrm{CD} 163^{+}$macrophages seem to be the main source of IL-18 (Stokman et al. 2016). In pediatric patients with chronic kidney allograft injury, $\mathrm{CD} 163^{+}$macrophages accumulate in areas of interstitial fibrosis and their numbers correlate with the parameters of kidney function (Ikezumi et al. 2015). $\mathrm{CD} 163^{+}$macrophages are preferentially present in transplanted endomyocardial tissue and increase upon acute cellular rejection of heart allograft (van den Bosch et al. 2017a). On the other hand, high numbers of $\mathrm{CD} 63^{+}$macrophages predict favorable early graft outcome in living donor liver transplantation (Nigam et al. 2018).

There are only limited data regarding CD163 expression on peripheral blood monocytes of organ transplant patients. In living kidney recipients, $\mathrm{CD} 63^{+}$monocytes increased immediately after the transplantation having a correlation with serum creatinine at one week and with a decrease of SCD163 serum levels (Guillen-Gomez et al. 2014). Also in our previous study in cadaveric donors, numbers of CD163 positive monocytes were highly upregulated at one week after kidney allograft transplantation (Sekerkova et al. 2014). Whether these CD163 positive peripheral monocytes represent cells with immunosuppressive capacity similar to M2 macrophages is not clear, yet. In a recent study, numbers of peripheral blood $\mathrm{CD} 163^{+} \mathrm{CD} 206^{+}$monocytes and their IL-10 production correlated positively with a progression of proteinuria in idiopathic membraneous nephropathy (Hou et al. 2018) suggesting their potential profibrotic effect.

Here, we aimed to elucidate whether CD163 expression is differently regulated in subpopulations of peripheral blood monocytes of kidney transplant recipients and has an association with the outcome. Next, we wondered whether membrane expression of CD163 on blood monocytes correlates with CD206, an alternative marker of M2 macrophages, and has a relationship with its soluble form (sCD163) and an anti-inflammatory cytokine IL-10 in serum samples. Additionally, regulation of CD163 by cytokines was tested in cultures of peripheral blood monocytes.

\section{Patients and Methods}

\section{Patients}

The group of 138 patients who underwent renal transplantation from deceased donor in Transplant Center of the Institute for Clinical and Experimental Medicine in Prague was enrolled in the prospective study. The study protocol was approved by the Ethics Committee of the Institute for Clinical and Experimental Medicine (ID 118099).

Patient characteristics are shown in Table 1. 
Table 1. Demographic characteristics.

\section{Normal outcome}

Number of patients ( $n$ )

94

Type of acute rejection ( $n, \%)$

Cellular

Humoral/DSA+

Humoral/DSA-

Gender (male/female) ( $n$ )

Recipient age (median, range)

Donor age (median, range)

$56.5(1-81)$

Cause of renal failure (n)

Glomerulonephritis

11

Tubulointerstitial nephritis

Vascular diseases

Diabetes mellitus

12

15

34

Other causes

$14(0-24)$

$93(98.9)$

$94(100)$

0

$10(0-98)$

$3(1-6)$

$8(8.5)$

0

$27(28.7)$

$59(62.8)$

$8(8.5)$

$3(3.2)$
Induction treatment and maintenance immunosuppression

All patients received induction treatment according to regular Transplant Center protocol. Primary kidney transplant recipients with panel reactive antibodies (PRA) $<20 \%$ and negative donor-specific antibodies (DSA) received basiliximab $(\mathrm{N}=43)$, patients with PRA $>20 \%$ were on rabbit anti-thymocyte globulin (ATG) $(\mathrm{N}=77)$, those with known DSA positivity at the time of transplantation $(\mathrm{N}=18)$ received plasma exchange $(\mathrm{PE})$ prior to transplantation and intravenous immunoglobulin (IVIG) in addition to ATG. Majority of patients $(\mathrm{N}=125)$ was treated by a triple maintenance therapy consisting of tacrolimus, mycophenolate mofetil, and corticosteroids. Target through levels of tacrolimus were $10-15 \mu \mathrm{g} / 1$ in the first month after transplantation with continuous cessation to 4-6 $\mu \mathrm{g} / \mathrm{l}$ after the third month. Ten patients were on dual therapy with tacrolimus and corticosteroids and remaining 3 were converted to everolimus in combination with 
mycophenolate mofetil and corticosteroids early after transplantation.

\section{Histopathology and rejection phenotypes}

Kidney allograft biopsy samples were obtained using a percutaneous ultrasound-guided 16G biopsy needle for scheduled (performed routinely at 3 months posttransplant) and "for-cause" biopsies. All patients gave their informed consent and signed their agreement with each biopsy performed.

Biopsy-proven acute rejection was diagnosed histologically according to the revised Banff '2017 classification (Haas et al. 2018). From 44 patients with acute rejection, 16 were classified as $\mathrm{T}$ cell-mediated rejection characterized by tubulointerstitial inflammation or intimal arteritis in the absence of C4d and DSA. Twenty-eight patients had histologic signs of antibodymediated rejection (glomerulitis, peritubular capillaritis and/or intimal arteritis in presence of $\mathrm{C} 4 \mathrm{~d}$, in absence of C4d the sum of microvascular inflammation was at least 2). DSA were detectable in 13 patients, remaining 15 patients had undetectable DSA and the diagnosis of antibody-mediated rejection was thus based on histology.

The most frequent first-line treatment in patients with cellular rejection were methylprednisolone pulses in 10 patients, ATG in 2 patients and 3 patients were judged as steroid-resistant and ATG was used as a rescue therapy. Patients with DSA positive humoral rejection were treated with methylprednisolone, plasma exchange (PE) and intravenous immunoglobulins (IVIG) in 9 cases, less intensive treatment with methylprednisolone only or adjustment of maintenance immunosuppression was used in remaining patients mostly due to infectious complications. Eleven of 13 DSA negative patients with histologic antibody-mediated rejection were treated with corticosteroids. In four of them, PE and IVIG were added and in two patients, adjustment of maintenance immunosuppression was performed.

\section{Tissue cultures of peripheral blood monocytes}

Peripheral blood samples were collected at following time-points: before kidney transplantation and day 7, 1 month, and 1 year post-transplantation. PBMCs were purified from buffy coats from healthy donors by standard Ficoll-Paque gradient centrifugation. Briefly, $3 \mathrm{ml}$ of Ficoll-Paque gradient was pipetted into a 15-ml centrifuge tube. The EDTA blood was diluted 1:1 in phosphate-buffered saline (PBS) and carefully layered over the Ficoll-Paque gradient $(6 \mathrm{ml} /$ tube $)$. The tubes were centrifuged for $30 \mathrm{~min}$ at $400 \times \mathrm{g}$. The cell interface layer was harvested carefully and the cells were washed once in PBS (for $10 \mathrm{~min}$ at $250 \times \mathrm{g}$ ) and were washed once again in RPMI-1640 medium (Sigma-Aldrich, St. Louis, MO, USA), (for $10 \mathrm{~min}$ at $250 \times \mathrm{g}$ ).

Cells were cultured in RPMI-1640 medium (Sigma-Aldrich, St. Louis, MO, USA), supplemented with $10 \%$ heat inactivated fetal bovine serum (FBS), L-glutamine, penicillin and streptomycin (Sigma-Aldrich). Cells were then removed into 6-well tissue culture plates (Costar, Corning, NY, USA) at density of $2 \times 10^{6}$ cells per $2 \mathrm{ml}$ per well and cultured under a $5 \% \mathrm{CO}_{2}$ atmosphere at $37{ }^{\circ} \mathrm{C}$. Monocytes seeded in 6-well tissue culture plates (Costar, Corning, NY, USA) at a density of $2 \times 10^{6} \mathrm{cells} / \mathrm{ml}$ were stimulated with IL-10 (R\&D Systems, Minneapolis, $\mathrm{MN}$, USA) at $10 \mathrm{ng} / \mathrm{ml}$, unstimulated cells were used as controls.

\section{Flow cytometry}

Peripheral blood mononuclear cells $(100 \mu \mathrm{l}$, approx. $1 \times 10^{6}$ ) were labeled with fluorochrome-conjugated monoclonal antibodies resuspended in PBS-BSA buffer for $20^{\prime}$ at room temperature (RT) in the dark. Following monoclonal antibodies were used: anti-CD163 (clone GHI61, PE or clone RM3/1, PE), anti-CD206 (clone 15-2, APC) purchased from BioLegend, San Diego, CA, USA; anti CD14 (RM052 clone, APC-Alexa Fluor 750), anti-CD16 (clone clone 3G8, Pacific, Blue), from Beckman Coulter, Brea, CA, USA. Samples were measured on Navios flow cytometer (Beckman Coulter, Brea, CA, USA) and analyzed using CxP software and Kaluza software (Beckman Coulter, Brea, CA, USA), the percentage of positive cells and mean intensity fluorescence (MFI) were evaluated for each individual marker. The gating strategy of $\mathrm{CD} 14^{+} \mathrm{CD} 16^{+}$ subpopulations is shown in Fig. 1.

\section{Statistics}

Statistical analyses were performed by GraphPad Prism 5 software (GraphPad Software, La Jolla, CA, USA). Based on the distribution of the data, parametric or nonparametric (Mann-Whitney, Kruskal-Wallis) testing was used. We performed logarithmical transformation and parametric testing by repeated measures ANOVA when comparing the flow cytometry data in different time-points. Clinical and flow cytometry data were correlated using Spearman rank correlation coefficient. Data were showed as median [min; max] according to the distribution and differences regarded statistically significant with $\mathrm{p}<0.05$. 


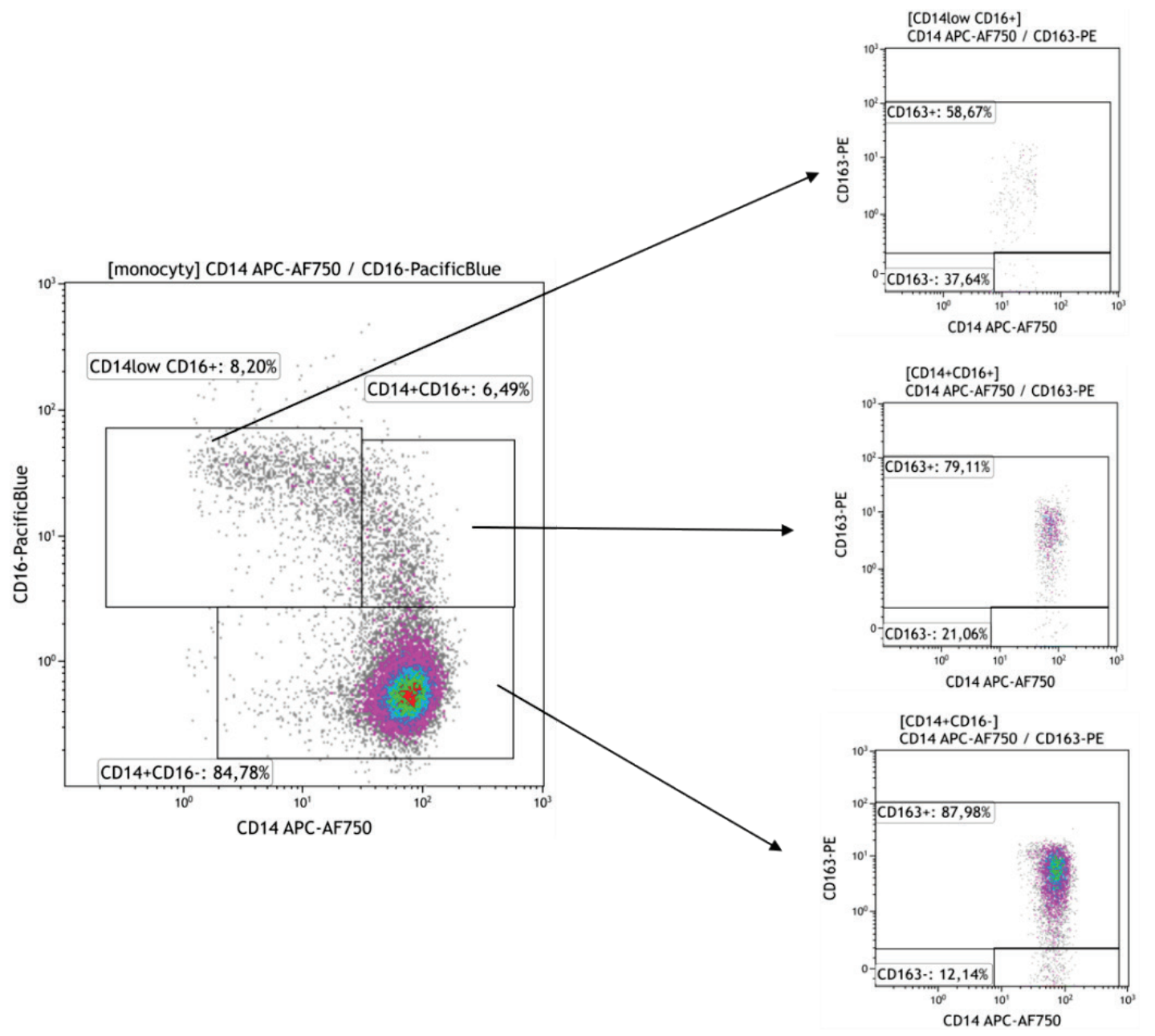

Fig. 1. The gating strategy to differentiate subpopulations of blood monocytes. Three subpopulations of peripheral blood monocytes were delineated by the expression level of $C D 14$ and $C D 16$ molecules into classical $\left(C D 14^{+} C D 16^{-}\right)$, intermediate $\left(C D 14^{+} C D 16^{+}\right)$and nonclassical $\left(\mathrm{CD} 14^{\mathrm{low}} \mathrm{CD} 16^{+}\right)$subsets (Fig. 1a). The expression of $\mathrm{CD} 163$ was then measured in the whole population of blood monocytes and selected three subpopulations.

\section{Results}

CD163 expression in different subpopulations of peripheral blood monocytes

The expression of CD163, a traditional marker of immunosuppressive M2 macrophages, was evaluated in peripheral blood monocytes subpopulations of patients before and one week, one month, and one year after kidney allograft transplantation. The subpopulations were consisted from the classical $\left(\mathrm{CD} 14^{+} \mathrm{CD} 16^{-}\right)$monocytes representing the predominant population and less frequently found intermediate $\left(\mathrm{CD} 14^{+} \mathrm{CD} 16^{+}\right)$and nonclassical $\left(\mathrm{CD} 14^{\text {low }} \mathrm{CD} 16^{+}\right)$monocytes with high proinflammatory potential. The membrane expression of CD163 was lower in nonclassical monocytes as compared to classical $(p<0.001)$ and intermediate $(p<0.001)$ ones and was markedly upregulated at one week after the transplantation in all three monocyte subpopulations $(\mathrm{p}<0.001$ for all comparisons) (Fig. 2). At one month, percentage of $\mathrm{CD} 63^{+}$cells decreased, particularly in non-classical monocytes $(\mathrm{p}<0.001)$ but did not reach pre-transplant levels. No difference between one month and one year was found in the proportion of $\mathrm{CD} 63^{+}$monocytes in any of subpopulations. Absolute numbers showed the same trend of CD163 induction after the transplantation but there was a decline of blood monocyte numbers after 1 month affecting proportionally all three subpopulations (data not shown).

The expression of CD163 in patients with acute rejection of kidney allograft

When comparing CD163 expression in relationship to clinical outcome, the upregulation of CD163 by peripheral blood monocytes after the transplantation was found in both patients with uncomplicated outcome $(\mathrm{p}<0.001)$ and those with acute rejection $(\mathrm{p}<0.001)$. Subjects with kidney allograft rejection had higher percentage of $\mathrm{CD} 63^{+}$monocytes before the trans- 
plantation $(p<0.05)$ (Fig. 3). The data were not affected by the type of rejection (antibody mediated rejection, cell mediated rejection). In most kidney transplant recipients, initial upregulation of CD163 was followed by a decrease at one month after the transplantation $(\mathrm{p}<0.001)$ and did not change at one year (Fig. 3).

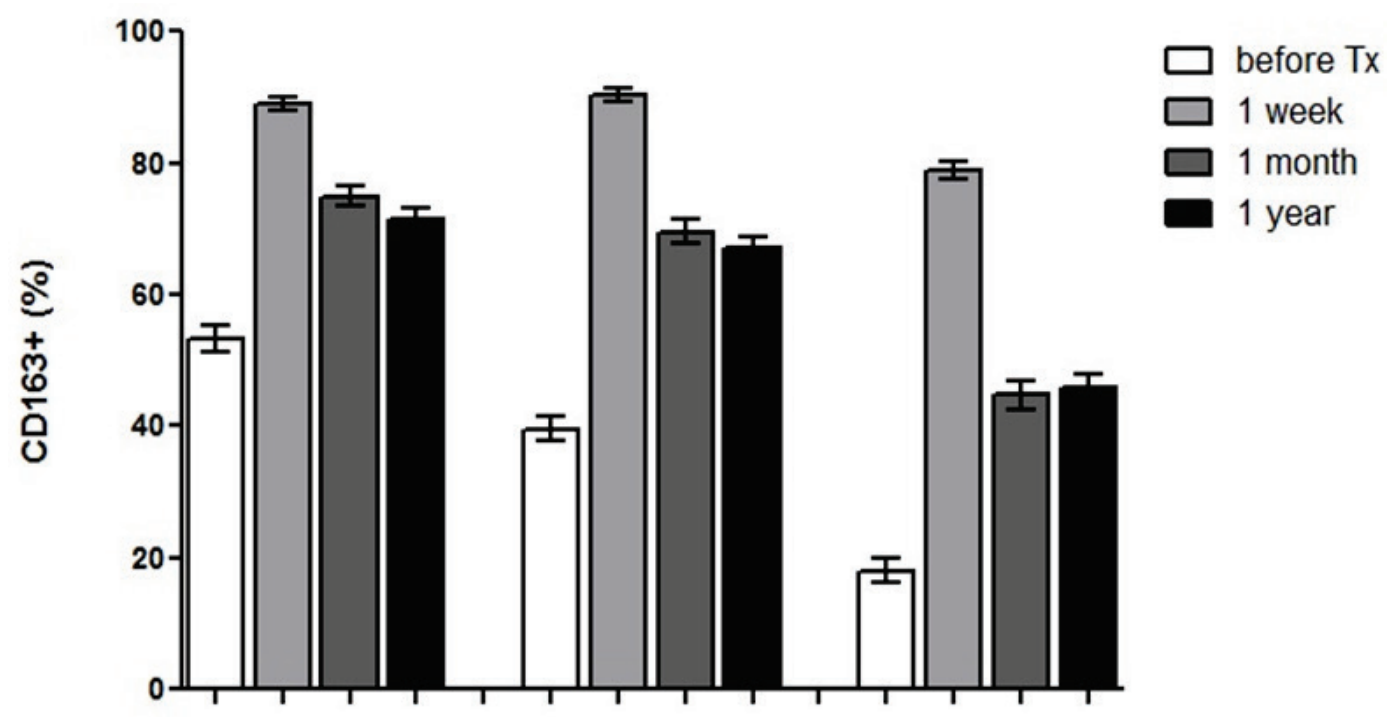

\section{CD14+ CD16- CD14+ CD16+ CD14low CD16+}

Fig. 2. CD163 expression in subpopulations of blood monocytes from kidney allograft recipients. The expression of CD163 was evaluated in classical $\left(\mathrm{CD} 14^{+} \mathrm{CD} 16^{-}\right)$, intermediate $\left(\mathrm{CD} 14^{+} \mathrm{CD} 16^{+}\right)$and nonclassical $\left(\mathrm{CD} 14^{\text {low }} \mathrm{CD} 16^{+}\right)$peripheral blood monocytes obtained from patients $(n=138)$ before the kidney transplantation and then one week, one month, and one year after the surgery. The percentage of CD163 positive cells was lower in nonclassical monocytes as compared to classical and intermediate ones $(p<0.001)$ but the expression of the molecule was upregulated at one week after the kidney transplantation in all three subsets $(p<0.001)$ and then decreased after one month $(p<0.001)$. The expression of CD163 after one year did not changed as compared to values at one month and remained higher as compared to pre-transplant percentage of positive cells $(p<0.001)$.

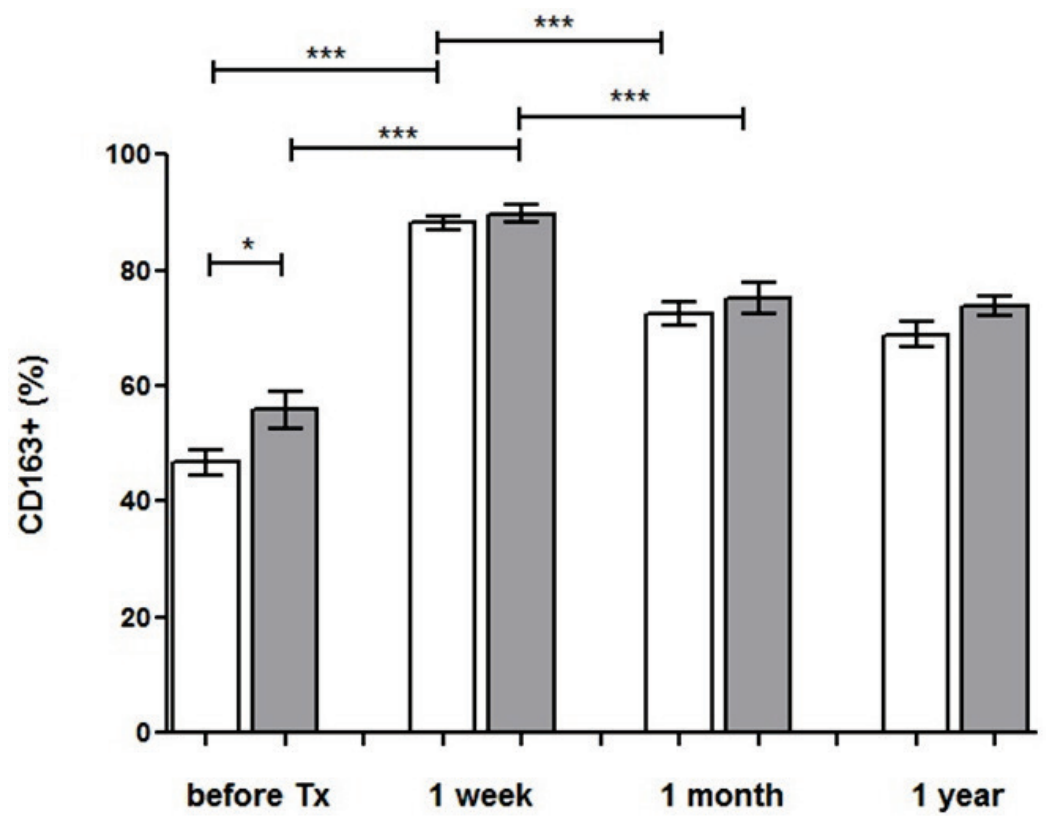

Fig. 3. CD163 expression after the transplantation in patients with acute rejection. The expression of CD163 was evaluated on blood monocytes obtained from patients before the kidney transplantation and one week after the surgery. We compared two groups of patients, those with uncomplicated outcome $(n=94)$ and those developing acute rejection $(n=44)$. Post-transplant CD163 expression was upregulated in both groups of patients but those with acute rejection had higher pre-transplant percentage of CD163 positive monocytes. The initial upregulation of CD163 was followed by a subsequent decrease at one month after the transplantation and did not change at 1 year. $* \mathrm{p}<0.05 ; * * * \mathrm{p}<0.001$. 
CD206 expression in peripheral blood monocytes of kidney allograft recipients

The expression of CD206, an alternative marker of M2 macrophages, on peripheral blood monocytes was much lower as compared to CD163 and these two markers of M2 macrophages did not show any mutual association. The expression of CD206 on peripheral blood monocytes (Fig. 4) was upregulated during the first week after kidney allograft transplantation only in acute rejection group $(\mathrm{p}<0.05)$.

In vitro modulation of CD163 and CD206 in blood monocytes

The expression of CD163 on monocytes derived from peripheral blood of healthy donors stimulated with IL-10 at $10 \mathrm{ng} / \mathrm{ml}$ increased in a culture until day 3 (Fig. 5ab). The expression of CD206 was also upregulated by IL-10 (Fig. $5 \mathrm{~cd}$ ) but, similarly to in vivo data, no correlation was found between the expression of CD163 and CD206 (data not shown). In our in vitro experiments, two anti-CD163 antibodies were used directed against different epitopes. When the analysis of CD163 expression by monocytes was performed from whole blood samples, RM3/1 clone of monoclonal antibody did not show any detectable expression but the staining pattern was observed fter the gradient separation of mononuclear cells or in buffy coats (6a). In a culture of separated mononuclear cells, both antibodies showed the same trend of CD163 induction by IL-10 (Fig. 6b).

\section{CD206}

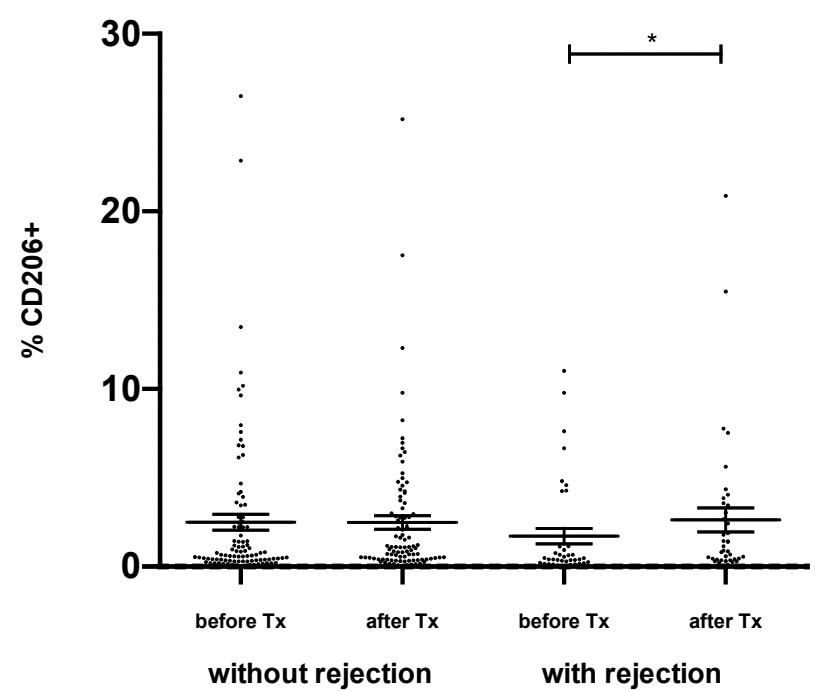

Fig. 4. CD206 expression in peripheral blood monocytes. In kidney transplant recipients, the expression of CD206 was determined on peripheral blood monocytes. The expression of CD206 was relatively low as compared to CD163 and increased during the first week after the transplantation only in patients with acute rejection. Data are expressed as mean $\pm \mathrm{SEM} ; * p<0.05$.
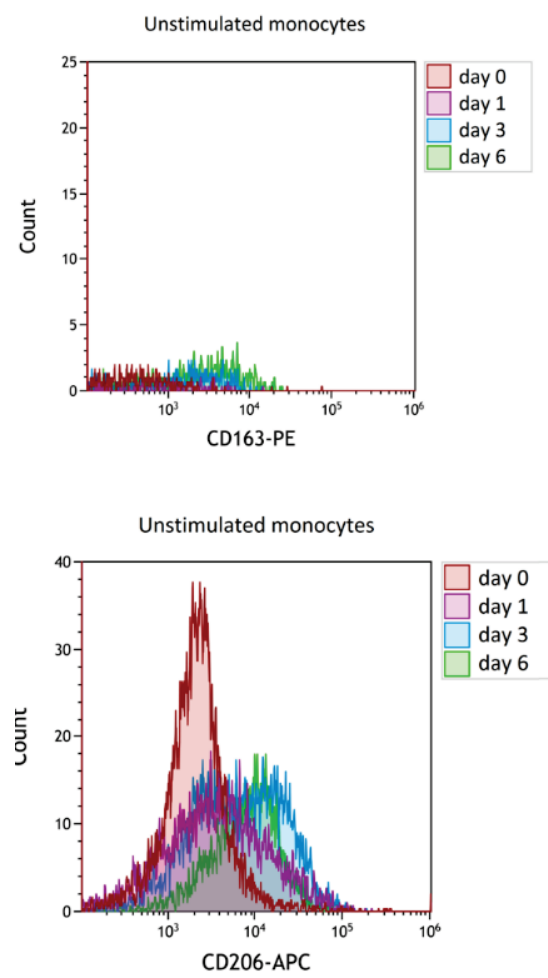

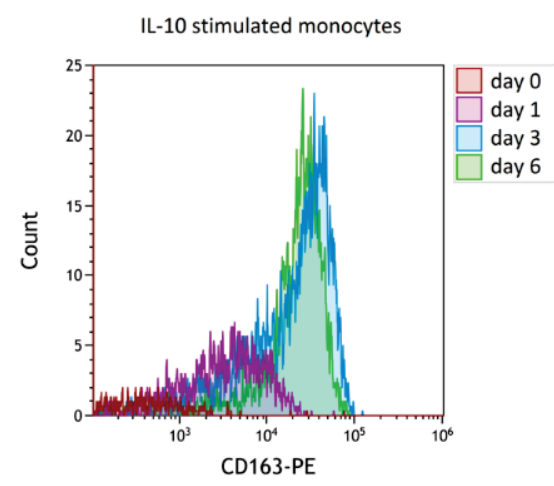

IL-10 stimulated monocytes

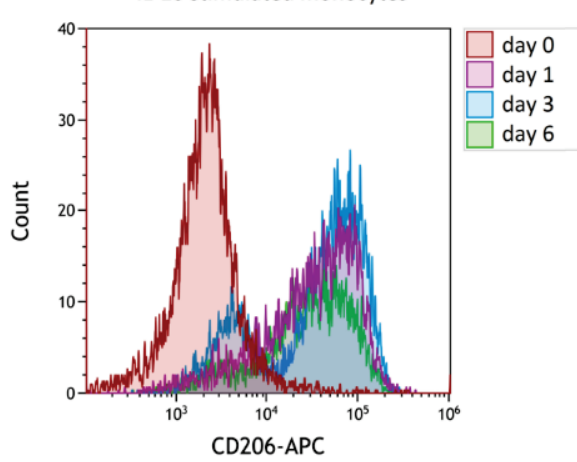

Fig. 5. Flow cytometry plots showing induction of CD163 and CD206 on cultured monocytes by IL-10. Peripheral blood mononuclear cells were cultured in the presence or absence of IL-10 $(10 \mathrm{ng} / \mathrm{ml})$ and the expression of CD163 and CD206 was analyzed on day 0 , day 1 , day 3 , and day 6. The expression of $C D 163$ on IL-10 stimulated monocytes increased dramatically on day 3 , CD206 expression was upregulated by IL-10 from day 1 . 


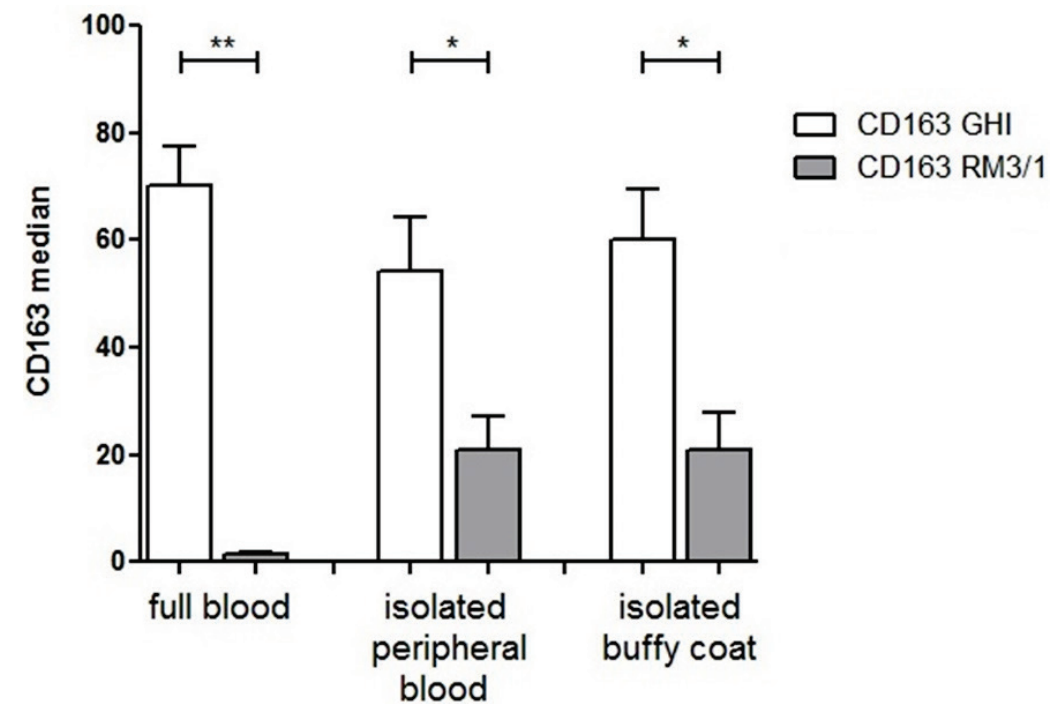

Fig. 6. Modulation of two different epitopes of CD163 by IL-10. Peripheral blood mononuclear cells were cultured for 6 days in the presence or absence of IL-10 $(10 \mathrm{ng} / \mathrm{ml})$ and the expression of CD163 was measured by two monoclonal antibodies (RM3/1 and GHI/61) recognizing different epitopes. In whole blood samples, only the GHI/61 clone showed clear membrane expression of CD163 in blood monocytes but staining by RM3/1 emerged after gradient centrifugation of mononuclear cells or in buffy coats (6a). In tissue cultures of mononuclear cells, both epitopes of CD163 on monocytes were markedly upregulated by IL-10 on day 3 (6b).

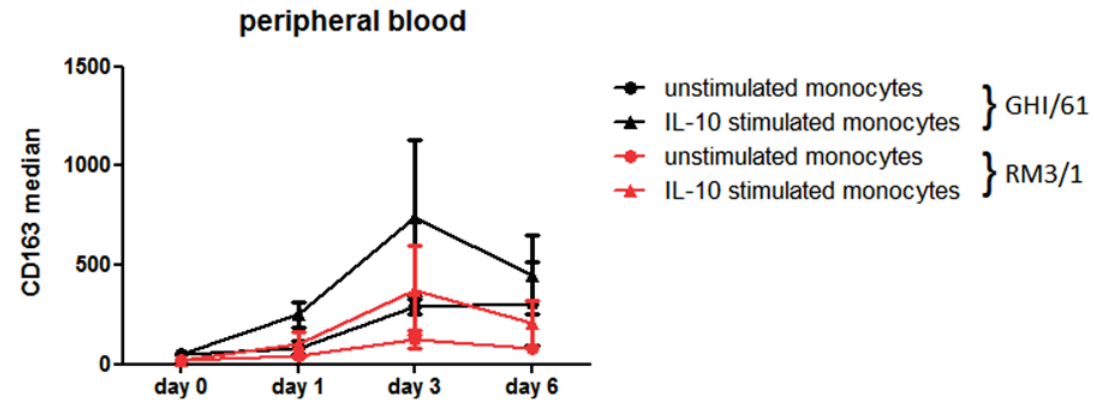

\section{Discussion}

Our data demonstrated in kidney allograft recipients, that CD163 expression was dramatically upregulated in all three subpopulations of peripheral blood monocytes including highly pro-inflammatory nonclassical $\left(\mathrm{CD} 14^{\text {low }} \mathrm{CD} 16^{+}\right)$subset. This observation is in contrast with traditional concept of CD163 as a marker of mononuclear phagocytes downregulating immune responses, specifically M2 macrophages (Hu et al. 2017). Also in our previous pilot study by Sekerkova et al. (2014), we presumed that $\mathrm{CD} 14^{+} \mathrm{CD} 16^{+}$monocytes (both intermediate and non-classical) are pro-inflammatory while $\mathrm{CD} 14^{+} \mathrm{CD} 163^{+}$are anti-inflammatory monocytes but our recent data demonstrated that this simplified classification is not valid. We can only speculate whether $\mathrm{CD} 206^{+}, \mathrm{CD} 163^{+}$, or double positive $\mathrm{CD} 163^{+} \mathrm{CD} 206^{+}$ monocytes represent a M2-like subset of monocytes with immunosuppressive properties but functional data are necessarily needed in this respect.

Pre-transplant distribution of classical, intermediate, and non-classical monocytes did not differ with respect to the clinical outcome as suggested by others (van den Bosch et al. 2017b). An alternative marker of M2 macrophages, CD206, did not correlate with the expression of CD163 on peripheral blood monocytes and showed post-transplant upregulation only in acute rejection group.

The expression of CD163 on blood monocytes before the transplantation was higher in patients in a risk of acute rejection in comparison with kidney allograft recipients with uncomplicated outcome. Furthermore, we observed comparable results in patients with $\mathrm{T}$ cell-mediated rejection and those with antibodymediated rejection, irrespective of their DSA status. The role of CD163 upregulation kidney transplantation is not clear but may reflect either higher need to eliminate hemoglobin/haptoglobin complexes in conditions of chronic tissue injury or a mechanism to increase TWEAK signaling important in post-ischemic repair (Akahori et al. 2015). In this respect, higher pre-transplant proportions of CD163 in patients at risk of acute rejection might be associated with more pronounced chronic inflammatory changes in renal parenchyma. There are multiple preexisting donor-derived factors affecting transplant outcome (Van Loon et al. 2020). This finding indirectly supports the view that $\mathrm{CD} 163^{+}$monocytes are functionally different from $\mathrm{CD}_{163}{ }^{+} \mathrm{M} 2$ tissue macrophages and probably do not exclusively downregulate immune responses. We suppose that the induction of 
CD163 on blood monocytes reflects rather the effect of immunosuppression than immune response against the kidney allograft. Recently, corticotherapy was found to upregulate CD163 expression by lung macrophages in patients with COPD (Higham et al. 2020).

The upregulation of CD163 by IL-10 has been already described by others (Ritter et al. 1999) but our in vitro experiments with cytokine stimulation of blood monocytes showed that also CD206 expression in cultured peripheral monocytes was induced by IL-10. In our previous study, upregulation of CD163 expression by monocytes has been shown in a culture with immunosuppressive drugs thymoglobulin or corticosteroids (Sekerkova et al. 2014) while calcineurin inhibitors targeting exclusively $\mathrm{T}$ lymphocytes (Hoskova et al. 2017) probably do not have any effect in this respect. We performed a couple of experiments with THP-1 monocyte/macrophage cell line where the percentage of $\mathrm{CD} 163^{+}$cells was much lower than in blood monocytes but the cytokine regulation showed the same trend (data not shown) with high variability between the single experiments. The reason to compare two monoclonal antibodies directed against different epitopes of CD163 emerged from our observation that RM3/1 antibody, excellent for staining of tissue M2 macrophages or a subset of alveolar macrophages (Striz et al. 1993), did not provide sufficient binding to peripheral blood monocytes and was thus replaced by
GHI/61 in our panel of antibodies. Under tissue culture conditions, both monoclonal antibodies showed the same profile of CD163 induction in response to IL-10. We can just speculate that CD163 three-dimensional conformation in fresh peripheral blood monocytes differs from those in tissue macrophages or cultured mononuclear phagocytes but different extracellular calcium dependence of different monoclonal antibodies (Maniecki et al. 2011) may play a role, too.

Mononuclear phagocytes represent an important part of immune system and some of their properties including memory (Saeed et al. 2014) or allorecognition (Zecher et al. 2009) lead us to revise the traditional view of innate and adaptive immunity (Cerny and Striz 2019). We believe that better understanding of mechanisms regulating phenotypic pattern of blood monocytes in kidney allograft transplantation might bring new potential biomarkers or therapeutic targets.

\section{Conflict of Interest}

There is no conflict of interest.

\section{Acknowledgements}

Supported by Ministry of Health of the Czech Republic (Grant Nr. 15-26883A). All rights reserved. Authors are indebted to Eva Fáberová and Veronika Běhalová for their excellent technical assistance.

\section{References}

AKAHORI H, KARMALI V, POLAVARAPU R, LYLE AN, WEISS D, SHIN E, HUSAIN A, NAQVI N, VAN DAM R, HABIB A, CHOI CU, KING AL, PACHURA K, TAYLOR WR, LEFER DJ, FINN AV: CD163 interacts with TWEAK to regulate tissue regeneration after ischaemic injury. Nat Commun 6: 7792, 2015. https://doi.org/10.1038/ncomms8792

BOWE B, XIE Y, XIAN H, LI T, AL-ALY Z: Association between monocyte count and risk of incident CKD and progression to ESRD. Clin J Am Soc Nephrol 12: 603-613, 2017. https://doi.org/10.2215/cjn.09710916

CERNY J, STRIZ I: Adaptive innate immunity or innate adaptive immunity? Clin Sci (Lond) 133: 1549-1565, 2019. https://doi.org/10.1042/cs20180548

CINKAJZLOVA A, LACINOVÁ Z, KLOUČKOVÁ J, KAVÁLKOVÁ P, TRACHTA M, KOSÁK M, KRÁTKÝ J, KASALICKÝ M, DOLEŽALOVÁ K, MRÁZ M, HALUZÍK M: An alternatively activated macrophage marker CD163 in severely obese patients: the influence of very low-calorie diet and bariatric surgery. Physiol Res 66: 641-652, 2017. https://doi.org/10.33549/physiolres.933522

DESY O, BELAND S, VALLIN P, RIOPEL J, LATULIPPE E, NAJAFIAN N, CHANDRAKER A, AGHARAZII M, BATAL I, DE SERRES SA: IL-6 production by monocytes is associated with graft function decline in patients with borderline changes suspicious for acute T-cell-mediated rejection: a pilot study. Transpl Int 31: 92-101, 2018. https://doi.org/10.1111/tri.13070 
DIGE A, STOY S, THOMSEN KL, HVAS CL, AGNHOLT J, DAHLERUP JF, MOLLER HJ, GRONBAEK H: Soluble CD163, a specific macrophage activation marker, is decreased by anti-TNF-alpha antibody treatment in active inflammatory bowel disease. Scand J Immunol 80: 417-423, 2014. https://doi.org/10.1111/sji.12222

ETZERODT A, RASMUSSEN MR, SVENDSEN P, CHALARIS A, SCHWARZ J, GALEA I, MOLLER HJ, MOESTRUP SK. Structural basis for inflammation-driven shedding of CD163 ectodomain and tumor necrosis factor-alpha in macrophages. J Biol Chem 289: 778-788, 2014. https://doi.org/10.1074/jbc.m113.520213

FABRIEK BO, DIJKSTRA CD, VAN DEN BERG TK: The macrophage scavenger receptor CD163. Immunobiology 210: 153-160, 2005. https://doi.org/10.1016/j.imbio.2005.05.010

FABRIEK BO, VAN BRUGGEN R, DENG DM, LIGTENBERG AJ, NAZMI K, SCHORNAGEL K, VLOET RP, DIJKSTRA CD, VAN DEN BERG TK: The macrophage scavenger receptor CD163 functions as an innate immune sensor for bacteria. Blood 113: 887-892, 2009. https://doi.org/10.1182/blood-2008-07-167064

GIRLANDA R, KLEINER DE, DUAN Z, FORD EA, WRIGHT EC, MANNON RB, KIRK AD: Monocyte infiltration and kidney allograft dysfunction during acute rejection. Am J Transplant 8: 600-607, 2008. https://doi.org/10.1111/j.1600-6143.2007.02109.x

GUILLÉN-GÓMEZ E, GUIRADO L, BELMONTE X, MADERUELO A, SANTÍN S, JUAREZ C, ARS E, FACUNDO C, BALLARÍN JA, VIDAL S, DÍAZ-ENCARNACIÓN MM: Monocyte implication in renal allograft dysfunction. Clin Exp Immunol 175: 323-331, 2014. https://doi.org/10.1111/cei.12228

HAAS M, LOUPY A, LEFAUCHEUR C, ROUFOSSE C, GLOTZ D, SERON D, NANKIVELL BJ, HALLORAN PF, COLVIN RB, AKALIN E, ALACHKAR N, BAGNASCO S, BOUATOU Y, BECKER JU, CORNELL LD, DUONG VAN HUYEN JP, GIBSON IW, KRAUS ES, MANNON RB, NAESENS M, ET AL.: The Banff 2017 Kidney Meeting Report: Revised diagnostic criteria for chronic active $\mathrm{T}$ cell-mediated rejection, antibody-mediated rejection, and prospects for integrative endpoints for next-generation clinical trials. Am J Transplant 18: 293-307, 2018. https://doi.org/10.1111/ajt.14625

HIGHAM A, SCOTT T, LI J, GASKELL R, DIKWA AB, SHAH R, MONTERO-FERNANDEZ MA, LEA S, SINGH D: Effects of corticosteroids on COPD lung macrophage phenotype and function. Clin Sci 134: 751-763, 2020. https://doi.org/10.1042/cs20191202

HOSKOVA L, MALEK I, KOPKAN L KAUTZNER J: Pathophysiological mechanisms of calcineurin inhibitorinduced nephrotoxicity and arterial hypertension. Physiol Res 66: 167-180, 2017. https://doi.org/10.33549/physiolres.933332

HOU J, ZHANG M, DING Y, WANG X, LI T, GAO P, JIANG Y: Circulating CD14(+)CD163(+)CD206(+) M2 monocytes are increased in patients with early stage of idiopathic membranous nephropathy. Mediators Inflamm 2018: 5270657, 2018. https://doi.org/10.1155/2018/5270657

HU JM, LIU K, LIU JH, JIANG XL, WANG XL, CHEN YZ, LI SG, ZOU H, PANG LJ, LIU CX, CUI XB, YANG L, ZHAO J, SHEN XH, JIANG JF, LIANG WH, YUAN XL, LI F: CD163 as a marker of M2 macrophage, contribute to predicte aggressiveness and prognosis of Kazakh esophageal squamous cell carcinoma. Oncotarget 8: 21526-21538, 2017. https://doi.org/10.18632/oncotarget.15630

IKEZUMI Y, SUZUKI T, YAMADA T, HASEGAWA H, KANEKO U, HARA M, YANAGIHARA T, NIKOLICPATERSON DJ, SAITOH A: Alternatively activated macrophages in the pathogenesis of chronic kidney allograft injury. Pediatr Nephrol 30: 1007-1017, 2015. https://doi.org/10.1007/s00467-014-3023-0

KIM J, CHOI SE, LIM BJ, KIM YS, HUH KH, LEE J, KIM SI, KIM MS, JEONG HJ: Clinical significance of macrophage polarization in antibody-mediated rejection of renal allograft. Transplant Proc 50: 1005-1008, 2018. https://doi.org/10.1016/j.transproceed.2018.02.037

MANIECKI MB, ETZERODT A, MOESTRUP SK, MOLLER HJ, GRAVERSEN JH: Comparative assessment of the recognition of domain-specific CD163 monoclonal antibodies in human monocytes explains wide discrepancy in reported levels of cellular surface CD163 expression. Immunobiology 216: 882-890, 2011. https://doi.org/10.1016/j.imbio.2011.02.001

MANIECKI MB, MOLLER HJ, MOESTRUP SK, MOLLER BK: CD163 positive subsets of blood dendritic cells: the scavenging macrophage receptors CD163 and CD91 are coexpressed on human dendritic cells and monocytes. Immunobiology 211: 407-417, 2006. https://doi.org/10.1016/j.imbio.2006.05.019 
MAYER A, LEE S, JUNG F, GRUTZ G, LENDLEIN A, HIEBL B: CD14+ CD163+ IL-10+ monocytes/macrophages: Pro-angiogenic and non pro-inflammatory isolation, enrichment and long-term secretion profile. Clin Hemorheol Microcirc 46: 217-223, 2010. https://doi.org/10.3233/ch-2010-1348

MOGHADDAM AS, MOHAMMADIAN S, VAZINI H, TAGHADOSI M, ESMAEILI SA, MARDANI F, SEIFI B, MOHAMMADI A, AFSHARI JT, SAHEBKAR A: Macrophage plasticity, polarization and function in health and disease. J Cell Physiol 233: 6425-6440, 2018. https://doi.org/10.1002/jcp.26429

MORENO JA, MUNOZ-GARCIA B, MARTIN-VENTURA JL, MADRIGAL-MATUTE J, ORBE J, PARAMO JA, ORTEGA L, EGIDO J, BLANCO-COLIO LM: The CD163-expressing macrophages recognize and internalize TWEAK: potential consequences in atherosclerosis. Atherosclerosis 207: 103-110, 2009. https://doi.org/10.1016/j.atherosclerosis.2009.04.033

NIGAM N, BIHARI C, LAL D, RASTOGI A, KUMAR S, PAMECHA V, KAUR S, KUMAR A, SARIN SK: Donor CD163 and nestin-positive cells predict graft function in living donor liver transplant. Clin Transplant 32: e13197, 2018. https://doi.org/10.1111/ctr.13197

ONG S-M, TENG K, NEWELL E, CHEN H, CHEN J, LOY T, YEO T-W, FINK K, WONG S-C: A novel, five-marker alternative to CD16-CD14 gating to identify the three human monocyte subsets. Front Immunol 10: 1761, 2019. https://doi.org/10.3389/fimmu.2019.01761

RITTER M, BUECHLER C, LANGMANN T, ORSO E, KLUCKEN J, SCHMITZ G: The scavenger receptor CD163: regulation, promoter structure and genomic organization. Pathobiology 67: 257-261, 1999. https://doi.org/10.1159/000028105

SAEED S, QUINTIN J, KERSTENS HHD, RAO NA, AGHAJANIREFAH A, MATARESE F, CHENG S-C, RATTER J, BERENTSEN K, VAN DER ENT MA, SHARIFI N, JANSSEN-MEGENS EM, TER HUURNE M, MANDOLI A, VAN SCHAIK T, NG A, BURDEN F, DOWNES K, FRONTINI M, KUMAR V: Epigenetic programming of monocyte-to-macrophage differentiation and trained innate immunity. Science 345: 1251086, 2014. https://doi.org/10.1126/science.1251086

SEKERKOVA A, KREPSOVA E, BRABCOVA E, SLATINSKA J, VIKLICKY O, LANSKA V, STRIZ I: $\mathrm{CD} 14+\mathrm{CD} 16+$ and $\mathrm{CD} 14+\mathrm{CD} 163+$ monocyte subpopulations in kidney allograft transplantation. BMC Immunol 15: 4, 2014. https://doi.org/10.1186/1471-2172-15-4

SHIN S, KIM YH, CHO YM, PARK Y, HAN S, CHOI BH, CHOI JY, HAN DJ: Interpreting CD56+ and CD163+ infiltrates in early versus late renal transplant biopsies. Am J Nephrol 41: 362-369, 2015. https://doi.org/10.1159/000430473

SHIRAISHI D, FUJIWARA Y, HORLAD H, SAITO Y, IRIKI T, TSUBOKI J, CHENG P, NAKAGATA N, MIZUTA H, BEKKI H, NAKASHIMA Y, ODA Y, TAKEYA M, KOMOHARA Y: CD163 is required for protumoral activation of macrophages in human and murine sarcoma. Cancer Res 78: 3255-3266, 2018. https://doi.org/10.1158/0008-5472.CAN-17-2011

SMILJANOVIC B, RADZIKOWSKA A, KUCA-WARNAWIN E, KUROWSKA W, GRÜN JR, STUHLMÜLLER B, BONIN M, SCHULTE-WREDE U, SÖRENSEN T, KYOGOKU C, BRUNS A, HERMANN S, OHRNDORF S, AUPPERLE K, BACKHAUS M, BURMESTER GR, RADBRUCH A, GRÜTZKAU A, MASLINSKI W, HÄUPL T: Monocyte alterations in rheumatoid arthritis are dominated by preterm release from bone marrow and prominent triggering in the joint. Ann Rheum Dis 77: 300-308, 2018. https://doi.org/10.1136/annrheumdis2017-211649

STANSFIELD BK, INGRAM DA: Clinical significance of monocyte heterogeneity. Clin Transl Med 4: 5, 2015. https://doi.org/10.1186/s40169-014-0040-3

STOKMAN G, KERS J, YAPICI Ü, HOELBEEK JJ, CLAESSEN N, DE BOER OJ, NETEA MG, HILBRANDS L, BEMELMAN FJ, TEN BERGE IJM, FLORQUIN S: Predominant tubular interleukin-18 expression in polyomavirus-associated nephropathy. $\quad$ Transplantation $\quad 100: \quad$ e88-e95, 2016. https://doi.org/10.1097/TP.0000000000001086

STRIZ I, WANG YM, SVARCOVA I, TRNKA L, SORG C, COSTABEL U: The phenotype of alveolar macrophages and its correlation with immune cells in bronchoalveolar lavage. Eur Respir J 6: 1287-1294, 1993.

TANIMURA H, MIZUNO K, OKAMOTO H: Serum levels of soluble CD163 as a specific marker of macrophage/monocyte activity in sarcoidosis patients. Sarcoidosis Vasc Diffuse Lung Dis 32: 99-105, 2015. 
TRAILIN A, HRUBA P, VIKLICKY O: Molecular assessment of kidney allografts: are we closer to a daily routine? Physiol Res 69: 215-226, 2020. https://doi.org/10.33549/physiolres.934278

VAN DEN BOSCH TP, CALISKAN K, KRAAIJ MD, CONSTANTINESCU AA, MANINTVELD OC, LEENEN PJ, VON DER THUSEN JH, CLAHSEN-VAN GRONINGEN MC, BAAN CC, ROWSHANI AT: $\mathrm{CD} 16+$ monocytes and skewed macrophage polarization toward M2 type hallmark heart transplant acute cellular rejection. Front Immunol 8: 346, 2017a. https://doi.org/10.3389/fimmu.2017.00346

VAN DEN BOSCH TPP, HILBRANDS LB, KRAAIJEVELD R, LITJENS NHR, REZAEE F, NIEBOER D, STEYERBERG EW, VAN GESTEL JA, ROELEN DL, CLAHSEN-VAN GRONINGEN MC, BAAN CC, ROWSHANI AT: Pretransplant numbers of CD16(+) monocytes as a novel biomarker to predict acute rejection after kidney transplantation: a pilot study. Am J Transplant 17: 2659-2667, 2017b. https://doi.org/10.1111/ajt.14280

VAN LOON E, BERNARDS J, VAN CRAENENBROECK AH, NAESENS M: The causes of kidney allograft failure: more than alloimmunity. a viewpoint article. Transplantation 104: e46-e56, 2020. https://doi.org/10.1097/tp.0000000000003012

WONG KL, TAI JJ, WONG WC, HAN H, SEM X, YEAP WH, KOURILSKY P, WONG SC: Gene expression profiling reveals the defining features of the classical, intermediate, and nonclassical human monocyte subsets. Blood 118: e16-e31, 2011. https://doi.org/10.1182/blood-2010-12-326355

ZECHER D, VAN ROOIJEN N, ROTHSTEIN DM, SHLOMCHIK WD, LAKKIS FG: An innate response to allogeneic nonself mediated by monocytes. J Immunol 183: 7810-7816, 2009. https://doi.org/10.4049/jimmunol.0902194

ZIEGLER-HEITBROCK L, ANCUTA P, CROWE S, DALOD M, GRAU V, HART DN, LEENEN PJM, LIU Y-J, MACPHERSON G, RANDOLPH GJ, SCHERBERICH J, SCHMITZ J, SHORTMAN K, SOZZANI S, STROBL H, ZEMBALA M, AUSTYN JM, LUTZ MB: Nomenclature of monocytes and dendritic cells in blood. Blood 116: e74-e80, 2010. https://doi.org/10.1182/blood-2010-02-258558 